\title{
Potential of PCSK9 as a new target for the management of LDL cholesterol
}

This article was published in the following Dove Press journal:

Research Reports in Clinical Cardiology

15 July 2015

Number of times this article has been viewed

\section{Guiliana Mombelli \\ Samuela Castelnuovo \\ Chiara Pavanello \\ Cardiovascular Department, Dyslipidemia Center, Azienda Ospedaliera Niguarda Cà Granda, Milan, Italy}

Correspondence: Guiliana Mombelli

Cardiovascular Department, Dyslipidemia

Center, Azienda Ospedaliera Niguarda

Cà Granda, Piazza Ospedale Maggiore 3, 20162 Milan, Italy

Email giuliana.mombelli@

ospedaleniguarda.it

\begin{abstract}
A large proportion of patients at high risk for cardiovascular disease continue to suffer from cardiovascular events despite current therapies. The need for additional therapies to lower the residual risk has led to research on new pharmacological approaches. The discovery of proteins regulating the activity of the low-density lipoprotein receptor has been a major breakthrough in the development of new cholesterol-lowering drugs. This review describes inhibition of proprotein convertase subtilisin/kexin type 9 (PCSK9) as a promising treatment for familial hypercholesterolemia, especially the relatively good short-term safety of PCSK9 inhibitors. In particular, we focus on its additive effect with statins and its advantage as a monotherapy in statin-intolerant patients. The additional low-density lipoprotein cholesterol lowering obtained with PCSK9 inhibition will be able to reduce the additional risk, but its effect on cardiovascular events has to be evaluated in future studies.
\end{abstract}

Keywords: proprotein convertase subtilisin/kexin type 9, PCSK9, additional or replacement therapy to statins, statin intolerance, residual cardiovascular risk

\section{Introduction}

In 2003, Abifadel et al discovered in two French families a new locus associated with an autosomal dominant form of familial hypercholesterolemia (FH3) and described two gain-of-function mutations in the 12-exon gene PCSK9 (1p34-32), which encodes for proprotein convertase subtilisin/kexin type-9 (PCSK9). ${ }^{1}$

Initially identified as neuronal apoptosis-regulated convertase-1, expressed in cerebellar neurons that undergo apoptosis, ${ }^{2}$ PCSK9 is a serine protease that plays a crucial role in cholesterol homeostasis, promoting degradation of the low-density lipoprotein (LDL) receptor. It is synthesized by the liver as a 692-amino acid soluble zymogen, made up of a signal peptide, a prodomain, and a catalytic triad, followed by a C-terminal domain. ${ }^{3}$ By autocatalytic intramolecular processing in the endoplasmic reticulum, the prodomain undergoes cleavage at position $152\left(\mathrm{Asp}_{151} / \mathrm{Gln}_{152}\right)$, allowing maturation and secretion of PCSK9. ${ }^{2}$

\section{Role of PCSK9}

PCSK9 binds to the extracellular domain of the LDL receptor, ie, in the first epidermal growth factor-like repeat homology domain, ${ }^{4}$ and is internalized along with the receptor in the cells. ${ }^{5}$ The binding site for the LDL receptor is on the surface of the catalytic domain containing Asp374. ${ }^{6}$ The C-terminal domain is not required for LDL receptor binding, but is necessary for internalization of the complex. ${ }^{7}$ Interestingly, PCSK9 may also bind to LDL receptor molecules intracellularly and regulate LDL receptor expression 
on the cell surface. ${ }^{8}$ Annexin A2, a protein involved in diverse cellular processes, binds to the C-terminal in the same way, but inhibits degradation of the receptor, demonstrating that this protein exerts an inhibitory function on PCSK9. ${ }^{9}$

Particularly important are the amino acid residues of the first epidermal growth factor-like repeat homology domain that coordinates the binding of calcium ions $\left(\mathrm{Asp}_{295}, \mathrm{Glu}_{296}\right.$, $\mathrm{Asp}_{310}, \mathrm{Tyr}_{315}$, and $\mathrm{His}_{306}$ ), which are responsible for the specificity of the interaction with PCSK $9 .{ }^{10}$ Some studies have demonstrated that PCSK9 locks the LDL receptor in an extended form, disrupting normal recycling of the LDL receptor by means of the cell surface. ${ }^{11}$ The PCSK9/LDL receptor complex moves to the endosomes by clathrin-mediated endocytosis, where the lower $\mathrm{pH}$ increases the strength of this binding against LDL/LDL receptor binding. This results in release of LDL cholesterol and direction of the PCSK9/ LDL receptor complex to the endosome ${ }^{12}$ (Figure 1). The ability of PCSK9 to promote cellular degradation of the receptor is not dependent on its catalytic activity, as demonstrated by discovery of a mutation that prevents autocatalytic processing and is associated with low LDL cholesterol levels. ${ }^{13}$ Subsequent studies investigated the molecular mechanism by which PCSK9 influences metabolism of LDL cholesterol. ${ }^{14}$ Beyond this activity, PCSK9 seems to be involved in degradation of the very low-density lipoprotein (VLDL) receptor and apolipoprotein E receptor $2,{ }^{15}$ suggesting a role in modulation of cellular functions. Recent intriguing studies have identified a direct association with plasma triglycerides, suggesting a potential effect of PCSK9 on triglyceride-rich lipoproteins. ${ }^{16,17}$ Confirming this observation, subjects carrying a PCSK9 gain-of-function mutation showed a three-fold elevation in apolipoprotein (apo)B100 production rates compared with normal subjects. ${ }^{18}$ Chan et al found that PCSK9 and apoC-III are inversely associated with the catabolic rate of triglyceride-rich lipoprotein-apoB48, suggesting a role of PCSK9 in the post-prandial coordination of the catabolism of this lipoprotein. ${ }^{19}$ Studies in hepatocytes found that PCSK9 binds to and reduces the intracellular degradation of apoB100 independently of LDL receptor levels and positively modulating the output of apoB. ${ }^{20}$ Contrasting data show that PCSK9 levels do not correlate with VLDL secretion or clearance in obese patients. ${ }^{21}$

Even if the liver is the main organ that regulates plasma PCSK9 levels, other tissues contribute to the production of this convertase $\mathrm{e}^{2,22-24}$ (Figure 2). Enterocytes express the LDL receptor on their basolateral surface and PCSK9 can possibly activate their degradation, modulating metabolism of cholesterol and chylomicrons. ${ }^{25}$ Some recent studies suggest a possible role of PCSK9 expressed in the kidney in modulating absorption of sodium by degradation of the

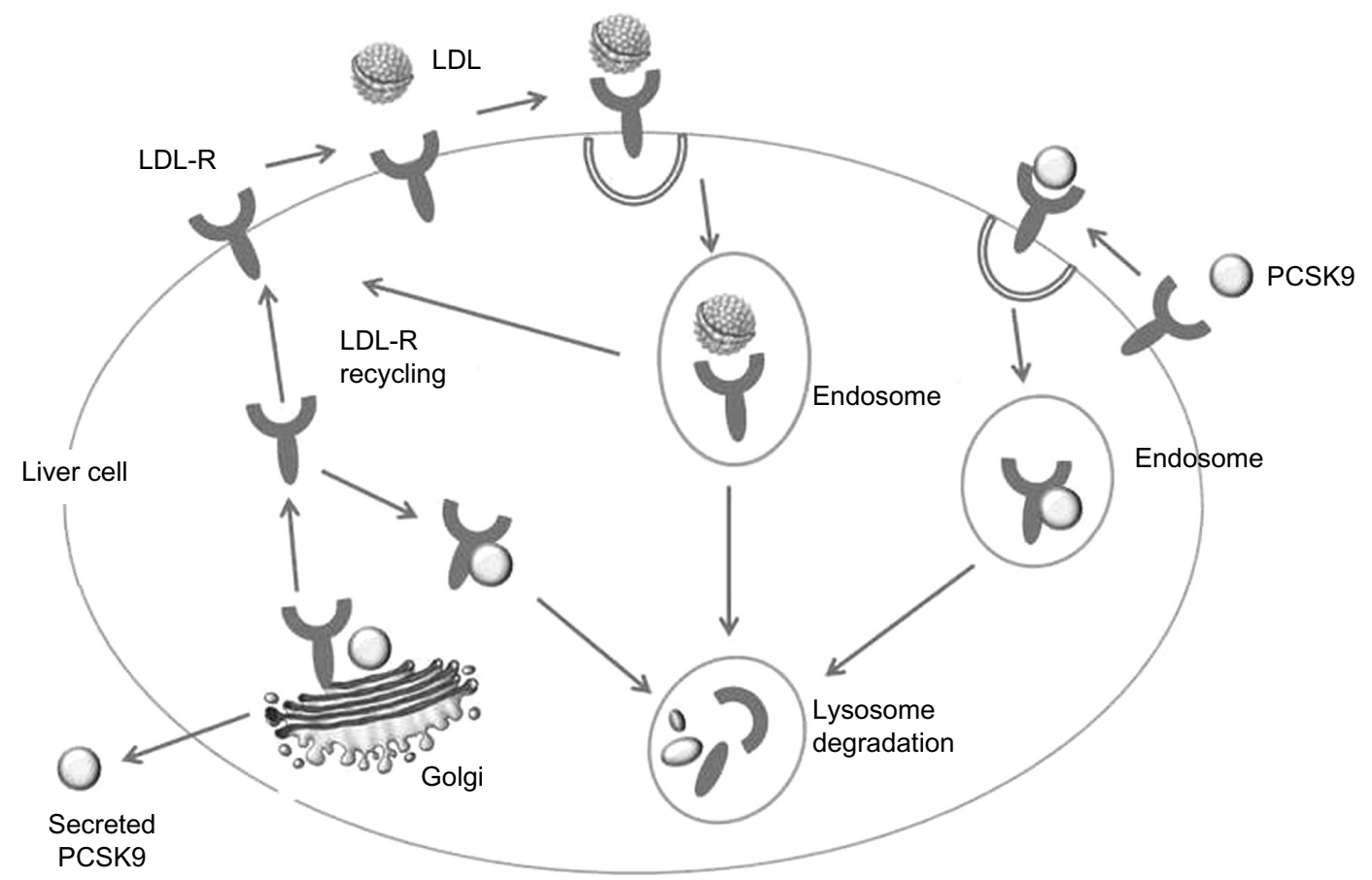

Figure I PCSK9 and LDL-R degradation.

Notes: PCSK9 regulates LDL-R expression. Circulating PCSK9 protein binds to the LDL-R. Once internalized into the liver cell, the PCSK9 protein directs the LDL-R to the lysosome for degradation. Intrinsically, PCSK9, secreted from the Golgi apparatus, binds the LDL-R before it reaches the cell surface and lead it to lysosomal degradation. Abbreviations: LDL-R, low-density lipoprotein cholesterol receptor; PCSK9, proprotein convertase subtilisin/kexin type 9. 


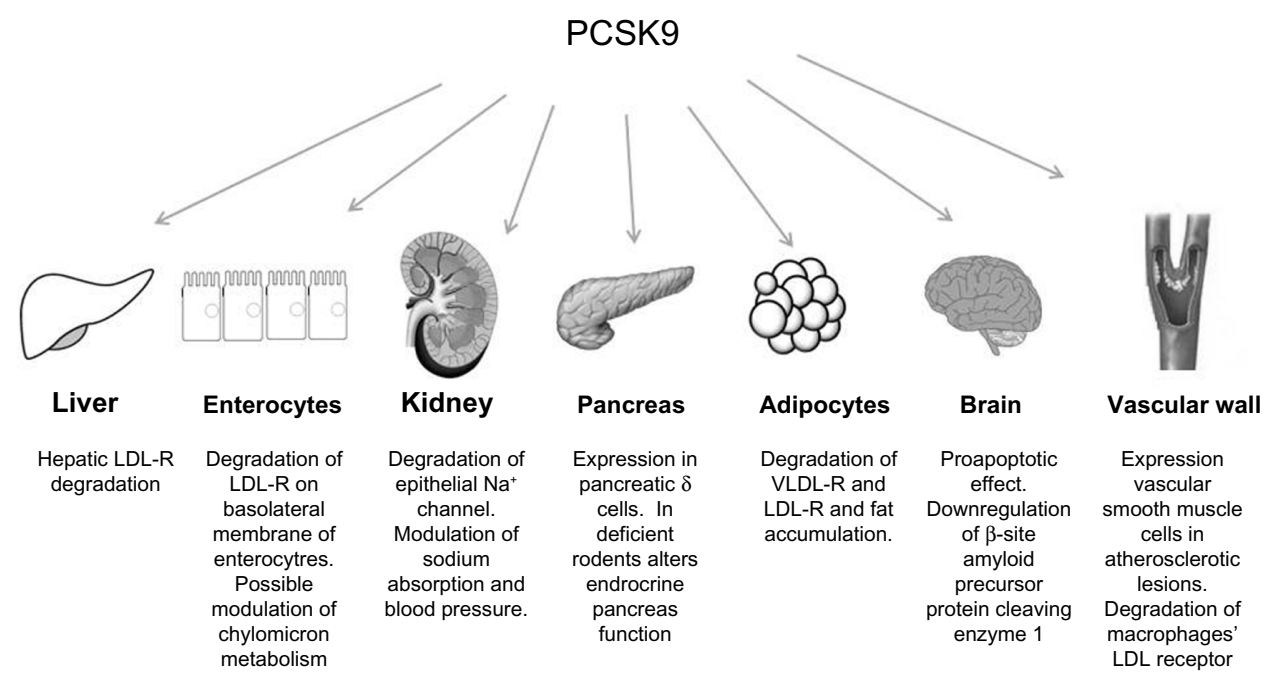

Figure 2 Role of PCSK9.

Abbreviations: LDL-R, low-density lipoprotein cholesterol receptor; VLDL-R, very low-density lipoprotein cholesterol receptor; PCSK9, proprotein convertase subtilisin/ kexin type 9 .

epithelial sodium channel and consequently playing a part in regulating blood pressure. ${ }^{26}$ PCSK9 was found in human $\delta$ pancreatic cells, but while in rodents its deficiency alters endocrine pancreatic function, such as insulin secretion, ${ }^{24}$ no effects have been demonstrated as yet in humans. ${ }^{27}$ Although adipocytes do not express PCSK9, they are rich in LDL and VLDL receptors, which play a fundamental role in hydrolysis of triglyceride-rich lipoproteins and are important for fat storage in these cells. ${ }^{28}$ Lakoski et al ${ }^{17}$ reported a positive correlation between plasma PCKS9 and body mass index.

In a recent animal study, the authors observed a proapoptotic effect in cerebellar neurons of PCSK9 (mediated by apoE receptor 2 degradation) that was independent of $\mathrm{N}$-methyl-D-aspartate receptor function. ${ }^{29}$ Some studies suggested involvement of this convertase in the development of Alzheimer's disease, ${ }^{30,31}$ in that it is able to generate amyloid $\beta$-peptide. ${ }^{32}$ Controversial findings came from other research. ${ }^{33}$ Interesting from a cardiovascular $(\mathrm{CV})$ point of view is the discovery by an Italian group of the presence of PCSK9 in human carotid atherosclerosis lesions, in particular in vascular smooth muscle cells. ${ }^{22}$ The proliferation of vascular smooth muscle cells express PCSK9, reducing macrophages LDL receptor levels. Other authors have observed an inverse correlation between carotid artery intima media thickness and expression of PCSK9, independently of LDL cholesterol. ${ }^{34,35}$ PCSK9 does not modulate the LDL receptor in all body tissues, but the existence of a tissue-specific cofactor has been suggested, which could explain the preferences for the liver for carrying out its activity. ${ }^{36}$

\section{Regulation of PCSK9}

Circulating PCSK9 follows a circadian rhythm in parallel with that of the biosynthesis of cholesterol, and seems to be regulated by hormones and nutritional status. ${ }^{37,38}$ In physiological conditions, plasma PCSK9 levels increase post-prandially, with a diurnal rhythm that mirrors hepatic cholesterol synthesis. ${ }^{39}$ The plasma concentration declines during the fasting period, reaching a minimum at 36 hours $(28 \%$ lower than in the fed state). ${ }^{38}$ Some authors found a correlation between PCSK9 levels and fasting serum glucose and insulin levels, suggesting a role of PCSK9 in the development of diabetes. ${ }^{17}$ This finding was not confirmed by other studies demonstrating that the degree of glucose intolerance is not associated with plasma PCSK9 levels; rather, the prevalence of diabetes modifies the relationship between plasma PCSK9, non-HDL (high-density lipoprotein) cholesterol, and apoB levels. ${ }^{40}$ Postmenopausal women have significantly higher plasma levels of PCSK9, which are unaffected by estrogen replacement therapy. ${ }^{17}$

Expression of PCSK9 is mainly controlled by cholesterol levels and transcription factor sterol-responsive element-binding protein (SREBP)-2, ${ }^{41,42}$ which coordinates numerous genes involved in cholesterol homeostasis, such as 3-hydroxy-3-methylglutaryl-coenzyme A reductase and LDL receptor expression. ${ }^{41,43}$ Mice that lack SREBP-2 have reduced PCSK9 mRNA levels. ${ }^{43}$

Circulating levels of PCSK9 can be explained by plasma LDL cholesterol concentrations, ${ }^{17,44}$ but LDL cholesterol levels do not fully reflect the activity of the protein for the following reasons: PCSK9 carries out its function in the intracellular compartment, and the antibodies used to dose 
this protein do not show selectivity for the active convertase, but bind furin-cleaved PCSK9.

Plasma PCSK9 is associated with LDL-apoB catabolism, ${ }^{45}$ and increased LDL catabolism effectively lowers plasma LDL cholesterol. ${ }^{46}$ PCSK9 and the LDL receptor are both regulated by SREBP, expression of which is upregulated in conditions of cellular cholesterol deficiency, ${ }^{37}$ and they are removed together in the lysosome. Using a validated mouse model, it has been demonstrated that the LDL receptor and PCSK9 are reciprocally regulated in a homeostatic pathway, where loss of the LDL receptor (eg, in patients with $\mathrm{FH}$ ) leads to accumulation of PCSK9, ${ }^{47}$ and in contrast, low levels of functional PCSK9 are followed by an increase in surface LDL receptor expression, which removes further plasma PCSK9. ${ }^{48}$

Statins increase PCSK9 levels and reduce those of LDL cholesterol. ${ }^{44,49}$ Other lipid-lowering treatments also affect plasma PCSK9 concentrations. Davignon et al showed that they are increased by increasing the statin dose and further increased when ezetimibe is added. ${ }^{50} \mathrm{~A}$ possible explanation lies in the reduction of intestinal cholesterol absorption and thus reduction of hepatic cholesterol that feedback regulates SREBP-2. ${ }^{51}$ Later studies reported different results showing that ezetimibe alone or combined with simvastatin is not associated with an increase in PCSK9. ${ }^{52}$ Fibrates significantly modified PCSK9 concentrations, but indirectly by modulating cholesterol levels. ${ }^{53}$ Bile acid binding resins were found to increase gene expression of PCSK9 in human liver biopsies $^{54}$ and lipoprotein apheresis reduces PCSK9 levels by $50 \%$, trapping LDL-bound and apoB-free PCSK9 in the apheretic column. ${ }^{48}$

Inactivation of PCSK9 seems to be mediated in hepatocytes by two proprotein convertases, ie, furin and PC5/6A, ${ }^{55}$ which cleave mature PCSK9, releasing an inactive truncated protein. Lack of these two convertases leads to elevated plasma LDL cholesterol levels.

\section{Genetic variants related to PCSK9}

Since the discovery in 2003 of two rare missense mutations (Ser127Arg and Phe216Leu), some other genetic variants of PCSK9, having a negative or positive effect on plasma concentrations of LDL cholesterol and CV disease have been described in the scientific literature. A gain-of-function mutation, Glu670Gly, has been associated with increased LDL cholesterol and coronary atherosclerosis, but not in those of Caucasian or African descent. ${ }^{56-59}$ In the Italian population, the same variant was associated with increased intima media thickness. ${ }^{60}$ The Asp374Tyr variant has been found in Utah, Norway, and England. ${ }^{61,62}$ Asn425Ser and Arg496Trp have been observed in patients with $\mathrm{FH}$ and concomitant mutations in the LDL receptor. ${ }^{63}$ In the Dallas Heart Study, two nonsense mutations (Tyr142X and Cys679X) were identified, which led to a loss-of-function of PCSK9 and were associated with VLDL cholesterol. ${ }^{56}$ The Ala443Thr variant in African Americans and the Arg46Leu variant in European Americans were associated with hypocholesterolemia. ${ }^{59}$ In the ARIC study, three single nucleotide polymorphisms that cause loss-of-function mutation (R46L, Y142X, and C679X) were associated with decreased LDL cholesterol and a lower risk of coronary events ${ }^{64}$ (Figure 3 ).

\section{CV disease and lipids}

CV disease is a leading cause of morbidity and mortality worldwide. ${ }^{65}$ In most cases, $\mathrm{CV}$ disease is caused by an atherosclerotic process strongly related to cholesterol levels, as many epidemiological studies have demonstrated. ${ }^{6}$ Increased LDL cholesterol is closely associated with the pathophysiology of $\mathrm{CV}$ disease, and accordingly, is a major risk factor for coronary artery disease (CAD). ${ }^{6}$ Therefore, investigation of the mechanisms and clinical management of LDL cholesterol in patients at high CV risk is of fundamental importance. Several scientific reports have focused attention on raised LDL cholesterol, considering this as the main lipid target for prevention of CV disease. These reports have included identification of LDL receptor mutations as the cause of $\mathrm{FH}^{67}$ and the LDL oxidation hypothesis, which has focused attention on LDL cholesterol. ${ }^{68}$

In contrast, HDL cholesterol is widely known as the "good cholesterol", because a number of studies have found a negative correlation between HDL cholesterol levels and

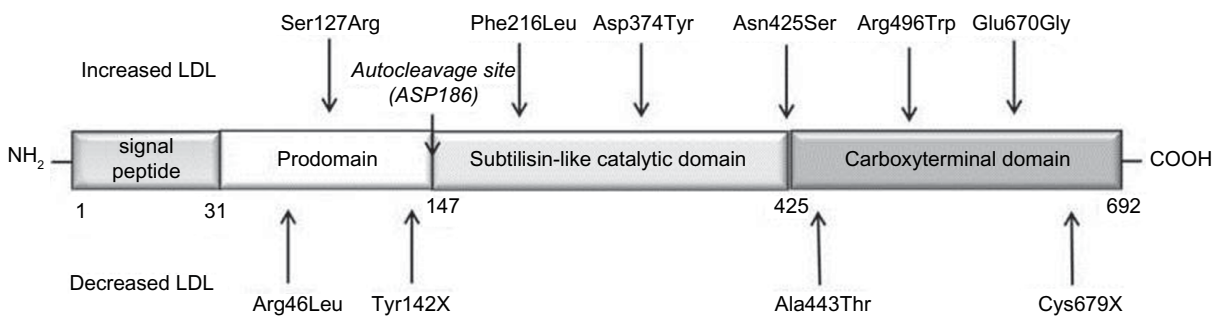

Figure 3 PCSK9 protein and its variants.

Abbreviations: LDL, low-density lipoprotein cholesterol; PCSK9, proprotein convertase subtilisin/kexin type 9. 
the risk of CV events. ${ }^{69,70} \mathrm{HDL}$ cholesterol has antiatherogenic properties, for instance, cholesterol is transported from peripheral tissues such as the cells in the arterial walls to the liver by HDL particles, where it is used for the composition of lipoproteins and synthesis of bile acids, steroid hormones, fat, and soluble vitamins, ${ }^{70}$ whereas low HDL cholesterol has often been observed as a component of metabolic syndrome, together with other determinants such as hyperglycemia, hypertriglyceridemia, high blood pressure, and high waist circumference. Each of these $\mathrm{CV}$ risk factors can promote the process of atherosclerosis. ${ }^{68}$

Indeed, Glomset et $\mathrm{al}^{71}$ have introduced the concept of reverse cholesterol transport and speculated that HDL promotes this process, becoming a protective factor against $\mathrm{CAD}$. An additional CV risk factor is high triglyceride levels. Several meta-analyses have shown that raised fasting and non-fasting triglyceride concentrations are associated with increased risk of CAD, even after adjustment for HDL cholesterol concentrations. ${ }^{72}$

Varbo et $\mathrm{al}^{73}$ reported that high triglyceride concentrations are strongly associated with low HDL cholesterol, and this has resulted in more detailed research on HDL in the past 15 years, with less focus on triglycerides. In the Emerging Risk Factors Collaboration, ${ }^{74,75}$ that included 302,430 individuals from 68 long-term, prospective studies, the authors reported that high triglyceride levels were associated with an increased risk of CAD and stroke (adjusted for age and sex). ${ }^{76}$ A final emergent independent $\mathrm{CV}$ risk factor is lipoprotein (a), ie, Lp(a), an interesting particle that combines the atherogenic properties of LDL cholesterol with the thrombogenic properties of inactivation of plasminogen. The phenotypic diversity of familial hyperlipoproteinemia (a) and $\mathrm{FH}$ as a population at high risk, and their frequent presence together with other $\mathrm{CV}$ risk factors, indicates that critical revision of the current diagnostic and therapeutic recommendations established for isolated familial hyperlipoprotein (a) and $\mathrm{FH}$ is needed.

Recently, Di Angelantonio et $\mathrm{al}^{76}$ discussed the importance of $\mathrm{Lp}(\mathrm{a})$ in stratification of people with intermediate and high CV risk, as advised by the European Atherosclerosis Society Consensus Panel, even if this recommendation was not supported by the American Heart Association Task Force. ${ }^{77}$ Konishi et $\mathrm{al}^{78}$ have published evidence that $\mathrm{Lp}(\mathrm{a}) \geq 30 \mathrm{mg} / \mathrm{dL}$ could be associated with a poor prognosis after percutaneous coronary intervention, even in patients who have achieved target lipid levels. Perhaps in this case we have to think of $\mathrm{Lp}(\mathrm{a})$ as being a residual risk factor in secondary prevention patients who achieve target lipid levels. Therefore, it could be concluded that elevated LDL cholesterol is the prime driver of atherogenesis, whereas other risk factors worsen atherosclerosis or precipitate its complications. If this is true, treatment of these accelerating risk factors should probably be accompanied by cholesterollowering therapy.

\section{PCSK9 inhibition as a lipid-lowering treatment}

Description of two homozygous PCSK9 loss-of-function mutations leading to VLDL cholesterol but having no association with evident phenotypic abnormalities points to the beneficial and safe hypolipidemic approach of PCSK9 inhibition. ${ }^{79,80}$ The ARIC study found a consistent reduction $(-88 \%)$ of CAD risk in those with the PCSK9 lossof-function mutation versus those without this mutation. ${ }^{81}$ Following on from this finding, some researchers have started to study inhibition of PCSK9, primarily using monoclonal antibodies.

Some are the advantages of the use of monoclonal antibodies for inhibition of a protein, eg, the potency and specificity. In addition, the long-term inhibitory effect allows a broader dose frequency. Several monoclonal antibodies against PCSK9 have been developed, and some of them have already demonstrated encouraging clinical results, eg, alirocumab (Sanofi-Regeneron), evolocumab (Amgen), and bococizumab (Pfizer). Other strategies for modulating PCSK9 include small-molecule inhibitors and hepatic gene silencing.

The first approach consists of an adnectin-based engineered protein that prevents PCSK9-LDL receptor binding. ${ }^{82}$ The reduced mass of this molecule, compared with monoclonal antibodies, makes it easier and cheaper to produce. However, it is characterized by rapid renal clearance and a short half-life. Serometrix LLC and Shifa Biomedical Corporation are now in the preclinical stages of developing two small chemical inhibitors for oral administration. ${ }^{83}$ The first consists of an allosteric ligand of PCSK9 that disrupts normal protein folding to inhibit LDL receptor binding; the second blocks the autocatalytic cleavage of PCSK9, preventing its secretion from the cell.

The second approach consists of engineered antisense oligonucleotides or small interfering RNA that direct sequencespecific degradation of mRNA, suppressing synthesis of the corresponding proteins. ALN-PCS02, developed by Alnylam Pharmaceuticals have concluded Phase I trials that have had promising results. ${ }^{84}$ Very recently, Pfizer has announced the development of a vaccine that stimulates the immune system to generate highly specific, long-lasting PCSK9 antibodies to overcome the relatively short life of monoclonal antibodies. ${ }^{85}$ 
Affiris AG anticipates promising preclinical results for its three vaccines, and clinical trials are expected to begin in $2015 .{ }^{86}$ Table 1 gives a summary of PCSK9 inhibitors in development.

\section{Antibodies against PCSK9 as additional therapy to statins}

Use of PCKS9 as add-on therapy to statins is supported by some observations. One of these arises from the limit of statins in reducing LDL cholesterol as a paradoxical effect. The cholesterol reduction exerts by statin activates SREBP-2, and consequently the transcription of 3-hydroxy3-methylglutaryl-coenzyme A reductase and PCSK9, as a feedback response, ${ }^{17}$ with consequent downregulation of the LDL receptor. Careskey et $\mathrm{al}^{87}$ observed that atorvastatin $40 \mathrm{mg} /$ day significantly increased circulating PCSK9 levels by $34 \%$ versus baseline. ${ }^{87}$ Other authors made the same observation for fibrates, although they affect these levels indirectly. ${ }^{53}$ In a study conducted by Berge et al ${ }^{88}$ reported the hyperresponsivity to statins of heterozygous PCSK9 loss of function carrier of heterozygous PCSK9 loss-of-function mutation. To date, many Phase III clinical trials, either concluded or ongoing, have demonstrated the efficacy and tolerability of PCSK9 monoclonal antibodies (Table 2).

The MENDEL-2 study that included 614 naive patients with moderate dyslipidemia (100 mg/dL $\leq$ LDL cholesterol $\geq 190 \mathrm{mg} / \mathrm{dL}$ ) showed that after 12 weeks of evolocumab, LDL cholesterol decreased by $55 \%-57 \%$ and by $38 \%-40 \%$ compared with ezetimibe. ${ }^{89}$ A concomitant study, LAPLACE-2, evaluated the efficacy of evolocumab as add-on treatment to statins versus placebo and versus ezetimibe. In 2,067 dyslipidemic patients have been randomized to assume a dosage to moderate-intensity (atorvastatin $10 \mathrm{mg}$, simvastatin $40 \mathrm{mg}$, or rosuvastatin $5 \mathrm{mg}$ ) or high-intensity (atorvastatin $80 \mathrm{mg}$, rosuvastatin $40 \mathrm{mg}$ ). A significant lowering of LDL cholesterol occurred in all groups treated with statins and evolocumab. In patients treated with atorvastatin $(10 \mathrm{mg}$ or $80 \mathrm{mg}$ ), addition of ezetimibe resulted in a reduction in LDL cholesterol values of $17 \%$ until to $24 \%$ from baseline, while addition of evolocumab administered every 2 weeks reduced LDL cholesterol values range $(61 \%-62 \%)$. Addition of evolocumab every 4 weeks reduced LDL cholesterol values (62\%-65\%) from baseline. ${ }^{90}$ This was the first study to demonstrate that addition of evolocumab causes similar reductions in LDL cholesterol and achieved LDL cholesterol levels, regardless of type of statin being taken at baseline, its dosage, or its intensity. ${ }^{90}$ The DESCARTES study enrolled 901 patients at high CV risk. Compared with placebo, the mean LDL cholesterol reductions from baseline on evolocumab at week 52 were $56 \%$ for the group with only dietary modifications, $62 \%$ for the group with diet changes and atorvastatin $10 \mathrm{mg}, 57 \%$ for the group with diet and atorvastatin $80 \mathrm{mg}$, and $49 \%$ for diet and atorvastatin $80 \mathrm{mg}$ plus ezetimibe $10 \mathrm{mg}$. The observed effect on PCSK9 levels and consequent reduction of LDL cholesterol levels were similar to those reported in patients receiving $10 \mathrm{mg}$ or $80 \mathrm{mg}$ of atorvastatin plus another PCSK9 monoclonal antibody, alirocumab (at a dose of $150 \mathrm{mg}$ ). ${ }^{76}$ The authors suggested that patients who have been already treated with high-dose statins alone or in combinations with other lipid-lowering therapies may have less capacity to further upregulate the LDL receptor with PCSK9 inhibition or may require higher doses of antibody. Although statins upregulate PCSK9, this does not explain why the reduction in LDL cholesterol levels associated with a low dose of a

Table I PCSK9 inhibitors in development

\begin{tabular}{|c|c|c|c|c|}
\hline Developer & Molecule & Description & Route of administration & Clinical stage \\
\hline Regeneron/Sanofi & Alirocumab & Fully human lgGI mAb & Subcutaneous & Phase III \\
\hline Amgen & Evolocumab & Fully human IgG2 mAb & Subcutaneous & Phase III \\
\hline Pfizer & Bococizumab & Humanized lgG2a mAb & Subcutaneous & Phase III \\
\hline Roche & RG-7652 & Humanized IgGI mAb & Subcutaneous & Phase II \\
\hline Eli Lilly Pharmaceuticals & LY-30I50I4 & Humanized IgG mAb & Subcutaneous & Phase II \\
\hline Alder Pharmaceuticals & ALD-306 & Humanized IgG mAb & Subcutaneous & Preclinical \\
\hline Pfizer & - & Vaccine & Subcutaneous & Preclinical \\
\hline Affiris AG & ATH05, ATH06, ATH07 & Vaccine & Subcutaneous & Preclinical \\
\hline Alnylam & ALN-PCSO2 & Small interfering RNA & Subcutaneous & Phase I \\
\hline Bristol-Myers Squibb & BMS-962476 & Small protein (adnectin) & Subcutaneous & Phase I \\
\hline Kowa Research Institute & $\mathrm{K}-3 \mathrm{I} 2$ & Synthetic compound & Oral & Phase I \\
\hline Serometrix LLC & SX-PCSK9 & Small molecule & Oral & Preclinical \\
\hline Shifa Biomedical Corporation & TBD & Small molecule & Oral & Preclinical \\
\hline Santaris Pharma A/S & SPC-500I & Antisense oligonucleotide & Subcutaneous & Phase I \\
\hline Idera Pharmaceuticals & - & Antisense oligonucleotide & Subcutaneous & Preclinical \\
\hline
\end{tabular}

Abbreviations: IgG, immunoglobulin G; mAb, monoclonal antibody; PCSK9, proprotein convertase subtilisin/kexin type 9. 
Table 2 Phase III trials on the PCSK9 inhibitors, alirocumab, evolocumab, and bococizumab

\begin{tabular}{|c|c|c|c|c|}
\hline Patients (n) & Population & Reference & Dose & Main results \\
\hline \multicolumn{5}{|c|}{ Phase III trials on alirocumab } \\
\hline 103 & Hypercholesterolemia (with or without statin therapy) & ODYSSEY MONO 95 & $\begin{array}{l}75 \mathrm{mg} \text { SC every } \\
2 \text { weeks }\end{array}$ & $\begin{array}{l}\text { LDL-C, }-47.2 \% ; \text { TC, } \\
-29.6 \% ; \text { HDL-C, }+6.0 \% \\
\text { Lp(a), }-16.7 \%\end{array}$ \\
\hline 251 & $\begin{array}{l}\text { Statin intolerance; primary hypercholesterolemia } \\
\text { (heterozygous FH or non-FH); and moderate, high, } \\
\text { or very high CVD risk (no statin therapy) }\end{array}$ & $\begin{array}{l}\text { ODYSSEY } \\
\text { ALTERNATIVE'I3 }\end{array}$ & $\begin{array}{l}75-150 \mathrm{mg} \text { SC } \\
\text { every } 2 \text { weeks }\end{array}$ & $\begin{array}{l}\text { LDL-C, }-52.2 \% \text {; lower rate } \\
\text { of muscle symptoms versus } \\
\text { ezetimibe }\end{array}$ \\
\hline 183 & $\begin{array}{l}\text { Hypercholesterolemia (heterozygous FH or non-FH) } \\
\text { not adequately controlled (atorvastatin with or without } \\
\text { other lipid-modifying therapy), and high CVD risk }\end{array}$ & $\begin{array}{l}\text { ODYSSEY } \\
\text { OPTIONS III3 }\end{array}$ & $\begin{array}{l}50-150 \text { SC every } \\
2 \text { weeks or } \\
200-400 \mathrm{mg} \\
\text { every } 4 \text { weeks }\end{array}$ & LDL-C, $-44 \%$ to $-54 \%$ \\
\hline 415 & $\begin{array}{l}\text { Hypercholesterolemia not adequately controlled } \\
\text { (rosuvastatin with or without other lipid-modifying } \\
\text { therapy), and high CVD risk }\end{array}$ & $\begin{array}{l}\text { ODYSSEY } \\
\text { OPTIONS IIII }\end{array}$ & $\begin{array}{l}75-150 \mathrm{mg} \mathrm{SC} \\
\text { every } 2 \text { weeks }\end{array}$ & LDL-C, $-36 \%$ to $-51 \%$ \\
\hline 316 & $\begin{array}{l}\text { Hypercholesterolemia not adequately controlled } \\
\text { (with maximum dose of a statin with or without } \\
\text { other lipid-modifying therapy), and high CVD risk }\end{array}$ & $\begin{array}{l}\text { ODYSSEY } \\
\text { COMBO I13 }\end{array}$ & $\begin{array}{l}75-150 \mathrm{mg} \mathrm{SC} \\
\text { every } 2 \text { weeks }\end{array}$ & LDL-C, $-48 \%$ \\
\hline 107 & $\begin{array}{l}\text { Heterozygous FH not adequately controlled with } \\
\text { current lipid-modifying therapy (no specification } \\
\text { regarding statin therapy) }\end{array}$ & $\begin{array}{l}\text { ODYSSEY } \\
\text { HIGH FH }\end{array}$ & $\begin{array}{l}150 \mathrm{mg} \text { SC every } \\
2 \text { weeks }\end{array}$ & LDL-C, $-46 \%$ \\
\hline 2,341 & $\begin{array}{l}\text { Hypercholesterolemia not adequately controlled } \\
\text { with current lipid-modifying therapy, and high CVD } \\
\text { risk (no specification regarding statin therapy) }\end{array}$ & $\begin{array}{l}\text { ODYSSEY LONG } \\
\text { TERM }{ }^{100}\end{array}$ & $\begin{array}{l}150 \mathrm{mg} \text { SC every } \\
2 \text { weeks }\end{array}$ & $\begin{array}{l}\text { LDL-C, }-62 \% \\
\text { After } 78 \text { weeks, event rate } \\
\text { I.7\% }\end{array}$ \\
\hline- & $\begin{array}{l}\text { Hypercholesterolemia not adequately controlled } \\
\text { (maximum dose of a statin with or without other } \\
\text { lipid-modifying therapy), and high CVD risk }\end{array}$ & ODYSSEY COMBO II & Ongoing & \\
\hline - & Hypercholesterolemia & ODYSSEY CHOICE I & Ongoing & \\
\hline- & $\begin{array}{l}\text { Heterozygous FH not adequately controlled with } \\
\text { current lipid-modifying therapy (no specification } \\
\text { regarding statin therapy) }\end{array}$ & ODYSSEY FH I & Ongoing & \\
\hline- & $\begin{array}{l}\text { Heterozygous FH not adequately controlled (with } \\
\text { maximally tolerated statin with or without other } \\
\text { lipid-modifying therapy) }\end{array}$ & ODYSSEY FH II & Ongoing & \\
\hline- & $\begin{array}{l}\text { Recent (in the past } 4-16 \text { weeks) acute coronary } \\
\text { syndrome event requiring hospitalization }\end{array}$ & $\begin{array}{l}\text { ODYSSEY } \\
\text { OUTCOMES }\end{array}$ & & \\
\hline 614 & $\begin{array}{l}\text { Framingham risk score } \leq 10 \% \text { and LDL-C level } \\
\geq 100 \mathrm{mg} / \mathrm{dL} \text { (no specification regarding statin therapy) }\end{array}$ & MENDEL-2 ${ }^{89}$ & $\begin{array}{l}\text { I } 40 \text { mg SC every } \\
2 \text { weeks or } 420 \mathrm{mg} \\
\text { every } 4 \text { weeks }\end{array}$ & $\begin{array}{l}\text { LDL-C, }-56.9 \% \text { to } 58.8 \% \\
\text { HDL-C, }+3.8 \% \text { to } 3.9 \% \\
\text { Lp(a), }-18.4 \% \text { to } 19.2 \%\end{array}$ \\
\hline 307 & $\begin{array}{l}\text { Statin intolerance; hypercholesterolemia (no statin } \\
\text { or low-dose statin) }\end{array}$ & GAUSS-2 $2^{109}$ & $\begin{array}{l}140 \mathrm{mg} \text { SC every } \\
2 \text { weeks or } 420 \mathrm{mg} \\
\text { every } 4 \text { weeks }\end{array}$ & $\begin{array}{l}\text { LDL-C, }-53 \% \text { to } 56 \% \text {, } \\
\text { lower rate of muscle } \\
\text { symptoms versus ezetimibe }\end{array}$ \\
\hline 901 & $\begin{array}{l}\text { LDL-C level } \geq 85 \mathrm{mg} / \mathrm{dL} \text { and either at ATP III target } \\
\text { with background lipid therapy or taking maximum } \\
\text { background lipid therapy (no specification regarding } \\
\text { statin therapy) }\end{array}$ & DESCARTES ${ }^{91}$ & $\begin{array}{l}420 \mathrm{mg} \text { SC every } \\
4 \text { weeks }\end{array}$ & LDL-C, $-48.5 \%$ to $61.6 \%$ \\
\hline 2,067 & $\begin{array}{l}\text { Primary hypercholesterolemia or mixed dyslipidemia } \\
\text { (taking statin therapy with or without ezetimibe) }\end{array}$ & LAPLACE- $2^{90}$ & $\begin{array}{l}\text { I } 40 \mathrm{mg} \text { SC every } \\
2 \text { weeks or } 420 \mathrm{mg} \\
\text { every } 4 \text { weeks }\end{array}$ & LDL-C, $-63 \%$ to $75 \%$ \\
\hline 331 & $\begin{array}{l}\text { Heterozygous } \mathrm{FH} \text { and } \mathrm{LDL}-\mathrm{C} \text { level } \geq 100 \mathrm{mg} / \mathrm{dL} \text { with } \\
\text { statin therapy (no specification regarding statin therapy) }\end{array}$ & RUTHERFORD- $2^{92}$ & $\begin{array}{l}\text { I } 40 \text { mg SC every } \\
2 \text { weeks or } 420 \mathrm{mg} \\
\text { every } 4 \text { weeks }\end{array}$ & $\begin{array}{l}\text { LDL-C, }-55.7 \% \text { to } 59.2 \% \\
\text { HDL-C, }+5.4 \% \text { to } 8.1 \% \\
\text { Lp(a), } 21.6 \% \text { to } 22.9 \%\end{array}$ \\
\hline 50 & $\begin{array}{l}\text { Homozygous } \mathrm{FH} \text { and } \mathrm{LDL}-\mathrm{C} \text { level }>130 \mathrm{mg} / \mathrm{dL} \text { with } \\
\text { stable lipid therapy (no specification regarding statin } \\
\text { therapy) }\end{array}$ & TESLA $^{93}$ & $\begin{array}{l}420 \mathrm{mg} \text { SC every } \\
4 \text { weeks }\end{array}$ & $\begin{array}{l}\text { LDL-C, }-23.1 \%, \text { HDL-C, } \\
4.0 \%, \operatorname{Lp}(\mathrm{a}),-12.7 \%\end{array}$ \\
\hline 4,465 & $\begin{array}{l}\text { Hypercholesterolemia or mixed dyslipidemia; } \\
\text { completion of previous evolocumab study } \\
\text { (no specification regarding statin therapy) }\end{array}$ & OSLER-2 ${ }^{99}$ & $\begin{array}{l}\text { I } 40 \text { mg SC every } \\
2 \text { weeks or } 420 \mathrm{mg} \\
\text { every } 4 \text { weeks }\end{array}$ & $\begin{array}{l}\text { LDL-C, }-61.0 \%, \text { I-year } \\
\text { event rate } 0.95 \%\end{array}$ \\
\hline
\end{tabular}

(Continued) 
Table 2 (Continued)

\begin{tabular}{|c|c|c|c|c|}
\hline Patients (n) & Population & Reference & Dose & Main results \\
\hline- & $\begin{array}{l}\text { Coronary heart disease; clinical indication for coronary } \\
\text { catheterization; and LDL-C level } \geq 80 \mathrm{mg} / \mathrm{dL} \text { or, with } \\
\text { additional risk factors, } \geq 60 \mathrm{mg} / \mathrm{dL} \text { and }<80 \mathrm{mg} / \mathrm{dL} \\
\text { (no specification regarding statin therapy) }\end{array}$ & GLAGOV & Ongoing & \\
\hline- & $\begin{array}{l}\text { Clinical CVD, high risk of recurrent CVD event, and } \\
\mathrm{LDL}-\mathrm{C} \text { level } \geq 70 \mathrm{mg} / \mathrm{dL} \text { or non-HDL-C } \geq 100 \mathrm{mg} / \mathrm{dL} \\
\text { (no specification regarding statin therapy) }\end{array}$ & FOURIER & Ongoing & \\
\hline- & $\begin{array}{l}\text { Heterozygous } \mathrm{FH} \text {; high or very high CVD risk; LDL-C } \\
\text { level }>70 \mathrm{mg} / \mathrm{dL} \text { and } \mathrm{TG} \text { level } \leq 400 \mathrm{mg} / \mathrm{dL} \\
\text { (with statin therapy) }\end{array}$ & SPIRE-HF & & Ongoing \\
\hline- & $\begin{array}{l}\text { High or very high CVD risk; LDL-C level }>70 \mathrm{mg} / \mathrm{dL} \\
\text { and TG level } \leq 400 \mathrm{mg} / \mathrm{dL} \text { (with statin therapy) }\end{array}$ & SPIRE-HR & & Ongoing \\
\hline- & $\begin{array}{l}\text { High or very high CVD risk; LDL-C level }>70 \mathrm{mg} / \mathrm{dL} \\
\text { and TG level } \leq 400 \mathrm{mg} / \mathrm{dL} \text { (with statin therapy) }\end{array}$ & SPIRE-LDL & & Ongoing \\
\hline- & $\begin{array}{l}\text { High CVD risk; LDL-C level } \geq 70 \mathrm{mg} / \mathrm{dL} \text { and } \\
<100 \mathrm{mg} / \mathrm{dL} \text {, or non-HDL-C level } \geq 100 \mathrm{mg} / \mathrm{dL} \\
\text { and }<130 \mathrm{mg} / \mathrm{dL} \text {, with lipid-lowering therapy } \\
\text { (no specification regarding statin therapy) }\end{array}$ & SPIRE-I & & Ongoing \\
\hline- & $\begin{array}{l}\text { High CVD risk; LDL-C level } \geq 100 \mathrm{mg} / \mathrm{dL} \text { or non- } \\
\text { HDL-C level } \geq 130 \mathrm{mg} / \mathrm{dL} \text {, with lipid-lowering } \\
\text { therapy (no specification regarding statin therapy) }\end{array}$ & SPIRE-2 & & Ongoing \\
\hline
\end{tabular}

Abbreviations: ATP III, Third Report of the National Cholesterol Education Program-Adult Treatment Panel; CVD, cardiovascular disease; LDL-C, low-density lipoprotein cholesterol; HDL-C, high-density lipoprotein cholesterol; Lp(a), lipoprotein(a); SC, subcutaneous; FH, familial hypercholesterolemia; TC, total cholesterol; PCSK9, proprotein convertase subtilisin/kexin type 9; TG, triglycerides.

statin is relatively large in comparison with the additional $6 \%$ reduction observed when the dose of statin is doubled. ${ }^{91}$ In all studies, the most common adverse events were flu-like symptoms, nasopharyngitis, upper respiratory tract infection, and back pain. The doubt about the efficacy of PCSK9 inhibition in FH was dispelled in the RUTHERFORD-2 study of 331 subjects with heterozygous $\mathrm{FH}$, in whom there was an LDL cholesterol reduction of approximately $60 \% .{ }^{92}$ Another Phase III trial conducted in 49 patients with homozygous FH (TESLA Part B) showed that evolocumab reduced LDL cholesterol by $30.9 \%$ when compared with placebo, with no occurrence of serious adverse events. ${ }^{93}$ The efficacy of alirocumab was initially tested in addition to atorvastatin in patients with primary hypercholesterolemia. After 12 weeks of treatment, LDL cholesterol decreased (by 39.6\%) on $50 \mathrm{mg}$ of alirocumab every 2 weeks and by $72.4 \%$ on $150 \mathrm{mg}$ every 2 weeks versus placebo. There was not much difference between the dose of $200 \mathrm{mg}$ and $300 \mathrm{mg}$ every 4 weeks ( $-43.2 \%$ and $-47.7 \%$, respectively). ${ }^{94}$ The ODYSSEY MONO study showed a similar profile of evolocumab in naive patients with moderate $\mathrm{CV}$ risk. LDL cholesterol was reduced by $47 \%$ with alirocumab $75 \mathrm{mg}$ every 2 weeks versus $16 \%$ with ezetimibe. Doubling the dose of the PCSK9 inhibitor, administered once a month, patients achieved a LDL cholesterol reduction of $54 \%{ }^{95}$ Gaudet et al ${ }^{96}$ investigated the effect of alirocumab on $\mathrm{Lp}(\mathrm{a})$ and found a significant reduction of about $30 \%$ from baseline versus a reduction of $0.3 \%$ with placebo. Pooled analysis of more than 1,300 patients in four evolocumab trials confirmed the efficacy of PCSK9 inhibition in reduction of $\mathrm{Lp}(\mathrm{a})$; a significant dose-related effect was observed, ie, $29.5 \%$ and $24.5 \%$ with $140 \mathrm{mg}$ and $420 \mathrm{mg}$, respectively. While the mean percentage reduction was significantly greater in patients with lower $\mathrm{Lp}(\mathrm{a})$ values at baseline, the absolute reduction was substantially greater in those with high baseline levels. ${ }^{97}$ Phase III trials with bococizumab are in progress. The first study, on heterozygous FH with high CV risk, is expected to be completed in January $2016 .{ }^{98}$ Endpoint trials, ie, ODYSSEY for alirocumab, FOURIER for evolocumab, and SPIRE for bococizumab, are currently in progress to evaluate reduction in $\mathrm{CV}$ risk. Preliminary data are available, and show a reduction of the rate of $\mathrm{CV}$ events at 1 year from $2.18 \%$ in the standard therapy group to $0.95 \%$ in the evolocumab group (hazard ratio for evolocumab group 0.47 ; $95 \%$ confidence interval $0.28-0.78, P=0.003) .{ }^{99}$ Similar results came out of a post hoc analysis of alirocumab, where the incidence of major adverse $\mathrm{CV}$ events was lower when compared with placebo (1.7\% versus $3.3 \%$, respectively; hazard ratio for alirocumab $0.52 ; 95 \%$ confidence interval $0.31-0.90, P=0.02){ }^{100}$

Clinical trials on evolocumab and alirocumab have reported a small but significant number of adverse neurocognitive effects in patients taking these drugs. Therefore, the 
US Food and Drug Administration has recently asked for an assessment of potential neurocognitive side effects, such as memory loss and confusion, and a new larger trial is underway to provide a more definitive assessment of safety over the longer term (ClinicalTrials.gov NCT02207634). The US Food and Drug Administration said it could not discuss specific development programs, but is "aware of concerns raised with neurocognitive adverse events and other lipid-lowering therapies, including statins, and as part of our oversight of new drug development, we are carefully monitoring these events". However, researchers have had difficulty finding a mechanism to explain these effects, since lipoproteins and monoclonal antibodies do not cross the blood-brain barrier. Furthermore, PCSK9 loss-of-function variants have not been associated with impaired cognitive performance. ${ }^{101}$

\section{Alternative therapy in statin intolerance}

The most common symptoms limiting statin use are muscular. ${ }^{102,103}$ Non-statin therapies are available, but the reduction of LDL cholesterol concentrations is very modest (15\%-20\%) compared with those obtained with a maximum statin regimen. ${ }^{104,105}$ Dosages intermittent to statin allow reductions from $12 \%$ to $38 \%$ of LDL cholesterol. ${ }^{104,106}$ Thus, patients at high $\mathrm{CV}$ risk, who are unable to tolerate effective doses of statins because of muscle-related side effects, represent a difficult population to treat. This population is steadily increasing, and needs alternative strategies to reduce CV risk.

An estimated $10 \%-20 \%$ of patients cannot tolerate statins or adequate doses of these agents to achieve treatment goals. However, this figure is not a reliable indicator of prevalence, because most patients with a clinical history of statin toxicity are excluded from the statin trials. The Effect of Statin Medications on Muscle Performance study reported that subjects treated with atorvastatin $80 \mathrm{mg}$ daily had more muscle symptoms than those treated with placebo $(9.4 \%$ versus $4.6 \%$, respectively). ${ }^{107}$ The GAUSS study assessed the efficacy and safety of evolocumab in patients with a documented history of adverse muscular effects from use of statins. Statin intolerance was defined as inability to tolerate at least one statin at any dose or an increase of the dose because of intolerable myalgia or myopathy, and having symptom improvement or resolution with discontinuation of the statin. A consistent dose-dependent reduction in LDL cholesterol levels versus baseline was found with evolocumab alone administered every 4 weeks ( $-40.8 \%$ on $280 \mathrm{mg},-42.6 \%$ on $350 \mathrm{mg}$, and $-50.7 \%$ on $420 \mathrm{mg}$ ). Addition of ezetimibe $10 \mathrm{mg}$ to the maximum dose of evolocumab produced an additional $12.3 \%$ reduction
( $-63 \%$ versus baseline). Ezetimibe achieved a reduction of $-14.8 \%$. In early trials, Lp(a) was reduced by a mean of $23.3 \%$ versus $7.9 \%$ with ezetimibe. Evolocumab increases HDL cholesterol modestly, from a minimum of about $6 \%$ to a maximum of $12 \%$ in combination to ezetimibe. Myalgia was the most common side effect $(7.4 \%$ with evolocumab versus $3.1 \%$ with ezetimibe). Patients on evolocumab/ezetimibe reported muscle side effects in $20 \%$ of cases. ${ }^{108}$ The GAUSS-2 study included patients intolerant to at least two statins, reflecting a population with a true unmet need. After 12 weeks of treatment, about $80 \%$ of evolocumab-treated patients and less than $10 \%$ of ezetimibe-treated patients at high risk achieved an LDL cholesterol $<100 \mathrm{mg} / \mathrm{dL}$.

In two Phase II trials of alirocumab with a stable dose of statin, muscle disorders were reported in $6 \%$ of patients treated with the PCSK9 inhibitor versus 7\% of patients on placebo. Further studies confirm a larger number of muscle symptoms in patients treated with alirocumab plus atorvastatin $80 \mathrm{mg}$ versus alirocumab plus atorvastatin $10 \mathrm{mg}(19 \%$ versus $6 \%$, respectively). Almost all patients tolerated the PCSK9 inhibitor well, with a low incidence of myalgia. ${ }^{109}$ In two Phase II trials (of alirocumab and a stable dose of statin), muscle disorders were reported in $6 \%$ of patients treated with the PCSK9 inhibitor versus 7\% of placebo patients. ${ }^{94,110}$ Further studies confirm a larger number of muscle symptoms in patients treated with alirocumab plus atorvastatin $80 \mathrm{mg}$ versus alirocumab plus atorvastatin $10 \mathrm{mg}$ (19\% versus $6 \%$, respectively). ${ }^{111}$ The ODYSSEY ALTERNATIVE trial tested the efficacy and safety of alirocumab versus ezetimibe in patients blindly rechallenged with atorvastatin $20 \mathrm{mg}$. The study included a 4-week period in which patients received only single-blind placebo. Patients who reported muscle symptoms during this period were not randomized, assuming that the symptoms were not statin-related. These controls were lacking in previous anti-PCSK9 trials that included the same population; considering that these allow more rigorous identification of patients intolerant to statins. ${ }^{112}$ Preliminary data presented by Moriarty et al at the 2014 annual meeting of the American Heart Association showed a significant 52.2\% reduction of LDL cholesterol with alirocumab versus $17.1 \%$ with ezetimibe after 24 weeks of treatment, with a lower rate of skeletal muscle adverse effects requiring discontinuation of treatment (15.9\% with alirocumab versus $20.2 \%$ and $22.2 \%$ with ezetimibe and atorvastatin, respectively). ${ }^{113}$ Treatment with evolocumab produced LDL cholesterol reductions of 41\%-63\% without significant muscle-related side effects. These reductions are comparable with those achieved using maximal doses of the most efficacious statins. ${ }^{108}$ The 
incidence of muscle-related adverse effects reported with evolocumab appears similar to that seen with alirocumab in patients who were able to tolerate background statins. ${ }^{94}$ Inhibition of PCSK9 using monoclonal antibody technology allows some advantages versus statins, potentially enabling the same results to be achieved.

Some statins are highly lipophilic whereas others are highly hydrophilic, so their kinetic profile is variable. ${ }^{114}$ Statins are substrates for several membrane transporters that can modify plasma concentrations of these drugs. Polymorphisms of cytochrome P450 enzymes and the $S L C O 1 B 1, A B C B 1$, and $C O Q 2$ genes may produce different and unpredictable statin metabolism and in some cases statin intolerance. ${ }^{115,116}$ While their metabolism is susceptible to some gene polymorphisms, monoclonal antibody concentrations are predictable, not being influenced by drug-drug interactions and possibly not causing muscle intolerance due to high concentrations. ${ }^{117}$ Few alternatives are available to date, and do not lower achieve the target LDL cholesterol concentrations expected by the European guidelines. If data from these short-term trials can be confirmed in larger cohorts, the muscle tolerability of these two PCSK9 inhibitors provides an alternative therapy in high-risk patients who have a poor possibility of treatment.

\section{Conclusion}

CV disease is a leading cause of death globally, and lipid modification, particularly lowering of LDL cholesterol, is one of the cornerstones of its prevention and treatment. However, even after lowering of LDL cholesterol to conventional goals, a sizeable number of patients continue to suffer $\mathrm{CV}$ events. More aggressive lowering of LDL cholesterol and optimization of other lipid parameters is required, given that triglycerides, HDL cholesterol, and Lp(a) are part of the residual $\mathrm{CV}$ risk, particularly in individuals with severe $\mathrm{FH}$. In this regard, it is necessary to consider new therapeutics, such as PCSK9 inhibitors, because LDL cholesterol cannot be lowered beyond a certain extent using traditional lipidlowering therapy. In patients without known CV disease, there is conflicting evidence as to the benefits of aggressive pursuit of numerical lipid targets, particularly with respect to all-cause mortality. Given the poor lipid control and problems related to the use of statins in patients at high CV risk, evaluation of new classes of lipid-lowering drugs that contribute to the reduction of adverse events becomes relevant. The results of the Phase II and III studies indicate that PCSK9 inhibitors are important innovative agents for reducing CV risk. It is important to consider using alternative agents with a low side effect profile in patients who are intolerant of statins, those with $\mathrm{FH}$, and those with $\mathrm{CV}$ events, considering that such patients have to take therapy lifelong. Such drugs are potentially usable for primary and secondary prevention in subjects at high CV risk in addition to statin therapy or as an alternative treatment in patients intolerant to statins, and have shown a good safety and tolerability profile; above all, they have shown good efficacy in achieving LDL cholesterol concentrations below $70 \mathrm{mg} / \mathrm{dL}$, as recommended the by European guidelines. The currently available data from Phase III studies confirm the safety, tolerability, and adherence to treatment with this new class of drugs. In particular, a future goal will determine whether, and how addict, to add these drugs to existing treatment or use them in place of statin therapy. Finally, PCSK9 can reduce the residual CV risk and could be a valid alternative to conventional treatment in patients intolerant or poorly responsive to statins. A metaanalysis by Sattar et al reported a higher risk of developing diabetes among patients taking statins (odds ratio 1.09; 95\% confidence interval 1.02-1.17). ${ }^{118}$ This increased risk is probably correlated with statin dose and potency, as suggested by other authors. ${ }^{119}$ Even if the risk is low when compared with the reduction of coronary events, association with PCSK9 inhibitors is likely to be useful in terms of reducing the statin dose and consequently the risk of developing diabetes.

Use of PCSK9 inhibitors is likely to be limited by cost factors. If the cost of other monoclonal antibodies is any indication, PCSK9 inhibitors will not be cheap. Pharma market experts have estimated an annual price that ranges from US\$7,000-\$12,000, ${ }^{120}$ which represents a huge expenditure considering the number of potentially eligible patients and the long-life duration of treatment. These new drugs may be more likely limited to patients with $\mathrm{FH}$ and those who are intolerant or not responsive to statins.

Another issue involves the new American College of Cardiology/American Heart Association guidelines for prevention of primary and secondary atherosclerotic disease, which recently suggested that a management to a specific LDL cholesterol goal is not appropriate, recommending that patients should be treated with a high-dose statin to lower cholesterol as far as possible. ${ }^{121}$ This "statin-centric" view of CV prevention could threaten the use or even approval of this new class of experimental cholesterol lowering drugs. In contrast, the European Society of Cardiology/European Atherosclerosis Society guidelines defining an LDL cholesterol target and leave it to clinicians to decide how to reach it.

\section{Disclosure}

The authors report no conflicts of interest in this work. 


\section{References}

1. Abifadel M, Varret M, Rabes JP, et al. Mutations in PCSK9 cause autosomal dominant hypercholesterolemia. Nat Genet. 2003;34(2): $154-156$.

2. Seidah NG, Benjannet S, Wickham L, et al. The secretory proprotein convertase neural apoptosis-regulated convertase 1 (NARC-1): liver regeneration and neuronal differentiation. Proc Natl Acad Sci U S A. 2003;100(3):928-933.

3. Benjannet S, Rhainds D, Essalmani R, et al. NARC-1/PCSK9 and its natural mutants: zymogen cleavage and effects on the low density lipoprotein (LDL) receptor and LDL cholesterol. J Biol Chem. 2004;279(47):48865-48875.

4. Zhang DW, Lagace TA, Garuti R, et al. Binding of proprotein convertase subtilisin/kexin type 9 to epidermal growth factor-like repeat A of low density lipoprotein receptor decreases receptor recycling and increases degradation. J Biol Chem. 2007;282(25):18602-18612.

5. Lagace TA, Curtis DE, Garuti R, et al. Secreted PCSK9 decreases the number of LDL receptors in hepatocytes and in livers of parabiotic mice. J Clin Invest. 2006;116(11):2995-3005.

6. Kwon HJ, Lagace TA, McNutt MC, Horton JD, Deisenhofer J. Molecular basis for LDL receptor recognition by PCSK9. Proc Natl Acad Sci U SA. 2008;105(6):1820-1825.

7. Ni YG, Condra JH, Orsatti L, et al. A proprotein convertase subtilisin-like/kexin type 9 (PCSK9) C-terminal domain antibody antigen-binding fragment inhibits PCSK9 internalization and restores low density lipoprotein uptake. J Biol Chem. 2010;285(17): 12882-12891.

8. Chan DC. Regulation of proprotein convertase subtilisin/kexin type 9: therapeutical perspectives. Atherosclerosis. 2011;217(1):77-79.

9. Mayer G, Poirier S, Seidah NG. Annexin A2 is a C-terminal PCSK9binding protein that regulates endogenous low density lipoprotein receptor levels. J Biol Chem. 2008;283(46):31791-31801.

10. Bottomley MJ, Cirillo A, Orsatti L, et al. Structural and biochemical characterization of the wild type PCSK9-EGF(AB) complex and natural familial hypercholesterolemia mutants. J Biol Chem. 2009;284(2): 1313-1323.

11. Lo Surdo P, Bottomley MJ, Calzetta A, et al. Mechanistic implications for LDL receptor degradation from the PCSK9/LDLR structure at neutral pH. EMBO Rep. 2011;12(12):1300-1305.

12. Yamamoto T, Lu C, Ryan RO. A two-step binding model of PCSK9 interaction with the low density lipoprotein receptor. $\mathrm{J}$ Biol Chem. 2011;286(7):5464-5470.

13. Mayne J, Dewpura T, Raymond A, et al. Novel loss-of-function PCSK9 variant is associated with low plasma LDL cholesterol in a FrenchCanadian family and with impaired processing and secretion in cell culture. Clin Chem. 2011;57(10):1415-1423.

14. Maxwell KN, Breslow JL. Adenoviral-mediated expression of PCSK 9 in mice results in a low-density lipoprotein receptor knockout phenotype. Proc Natl Acad Sci U S A. 2004;101(18):7100-7105.

15. Poirier $\mathrm{S}$, Mayer G, Benjannet $\mathrm{S}$, et al. The proprotein convertase PCSK9 induces the degradation of low density lipoprotein receptor (LDLR) and its closest family members VLDLR and ApoER2. J Biol Chem. 2008;283(4):2363-2372.

16. Cariou B, Langhi C, Le Bras M, et al. Plasma PCSK9 concentrations during an oral fat load and after short term high-fat, high-fat high-protein and high-fructose diets. Nutr Metab (Lond). 2013;10(1):4.

17. Lakoski SG, Lagace TA, Cohen JC, Horton JD, Hobbs HH. Genetic and metabolic determinants of plasma PCSK9 levels. J Clin Endocrinol Metab. 2009;94(7):2537-2543.

18. Sun XM, Eden ER, Tosi I, et al. Evidence for effect of mutant PCSK9 on apolipoprotein B secretion as the cause of unusually severe dominant hypercholesterolemia. Hum Mol Genet. 2005;14(9):1161-1169.

19. Chan DC, Wong AT, Pang J, Barrett PH, Watts GF. Inter-relationships between proprotein convertase subtilisin/kexin type 9, apolipoprotein C-III and plasma apolipoprotein B-48 transport in obese subjects: a stable isotope study in the postprandial state. Clin Sci. 2015;128(6): 379-385.
20. Sun H, Samarghandi A, Zhang N, Yao Z, Xiong M, Teng BB. Proprotein convertase subtilisin/kexin type 9 interacts with apolipoprotein $\mathrm{B}$ and prevents its intracellular degradation, irrespective of the low-density lipoprotein receptor. Arterioscler Thromb Vasc Biol. 2012;32(7): 1585-1595.

21. Sullivan S, Fabbrini E, Horton JD, Korenblat K, Patterson BW, Klein S. Lack of a relationship between plasma PCSK9 concentrations and hepatic lipoprotein kinetics in obese people. Transl Res. 2011;158(5): 302-306.

22. Ferri N, Tibolla G, Pirillo A, et al. Proprotein convertase subtilisin kexin type 9 (PCSK9) secreted by cultured smooth muscle cells reduces macrophages LDLR levels. Atherosclerosis. 2012;220(2): 381-386.

23. Le May C, Kourimate S, Langhi C, et al. Proprotein convertase subtilisin kexin type 9 null mice are protected from postprandial triglyceridemia. Arterioscler Thromb Vasc Biol. 2009;29(5):684-690.

24. Langhi C, Le May C, Gmyr V, et al. PCSK9 is expressed in pancreatic delta-cells and does not alter insulin secretion. Biochem Biophys Res Commun. 2009;390(4):1288-1293.

25. Levy E, Ben Djoudi Ouadda A, Spahis S, et al. PCSK9 plays a significant role in cholesterol homeostasis and lipid transport in intestinal epithelial cells. Atherosclerosis. 2013;227(2):297-306.

26. Sharotri V, Collier DM, Olson DR, Zhou R, Snyder PM. Regulation of epithelial sodium channel trafficking by proprotein convertase subtilisin/ kexin type 9 (PCSK9). J Biol Chem. 2012;287(23):19266-19274.

27. Mbikay M, Sirois F, Mayne J, et al. PCSK9-deficient mice exhibit impaired glucose tolerance and pancreatic islet abnormalities. FEBS Lett. 2010;584(4):701-706.

28. Roubtsova A, Munkonda MN, Awan Z, et al. Circulating proprotein convertase subtilisin/kexin 9 (PCSK9) regulates VLDLR protein and triglyceride accumulation in visceral adipose tissue. Arterioscler Thromb Vasc Biol. 2011;31(4):785-791.

29. Kysenius K, Muggalla P, Matlik K, Arumae U, Huttunen HJ. PCSK9 regulates neuronal apoptosis by adjusting ApoER2 levels and signaling. Cell Mol Life Sci. 2012;69(11):1903-1916.

30. Casserly I, Topol E. Convergence of atherosclerosis and Alzheimer's disease: inflammation, cholesterol, and misfolded proteins. Lancet. 2004;363(9415):1139-1146.

31. Mahley RW, Weisgraber KH, Huang Y. Apolipoprotein E4: a causative factor and therapeutic target in neuropathology, including Alzheimer's disease. Proc Natl Acad Sci U S A. 2006;103(15):5644-5651.

32. Jonas MC, Costantini C, Puglielli L. PCSK9 is required for the disposal of non-acetylated intermediates of the nascent membrane protein BACE1. EMBO Rep. 2008;9(9):916-922.

33. Liu M, Wu G, Baysarowich J, et al. PCSK9 is not involved in the degradation of LDL receptors and BACE1 in the adult mouse brain. J Lipid Res. 2010;51(9):2611-2618.

34. Huijgen R, Fouchier SW, Denoun M, et al. Plasma levels of PCSK9 and phenotypic variability in familial hypercholesterolemia. J Lipid Res. 2012;53(5):979-983.

35. Lee CJ, Lee YH, Park SW, et al. Association of serum proprotein convertase subtilisin/kexin type 9 with carotid intima media thickness in hypertensive subjects. Metabolism. 2013;62(6): 845-850.

36. Grefhorst A, McNutt MC, Lagace TA, Horton JD. Plasma PCSK9 preferentially reduces liver LDL receptors in mice. J Lipid Res. 2008;49(6): 1303-1311.

37. Costet P, Cariou B, Lambert G, et al. Hepatic PCSK9 expression is regulated by nutritional status via insulin and sterol regulatory elementbinding protein 1c. J Biol Chem. 2006;281(10):6211-6218.

38. Browning JD, Horton JD. Fasting reduces plasma proprotein convertase, subtilisin/kexin type 9 and cholesterol biosynthesis in humans. J Lipid Res. 2010;51(11):3359-3363.

39. Persson L, Cao G, Stahle L, et al. Circulating proprotein convertase subtilisin kexin type 9 has a diurnal rhythm synchronous with cholesterol synthesis and is reduced by fasting in humans. Arterioscler Thromb Vasc Biol. 2010;30(12):2666-2672. 
40. Brouwers MC, Troutt JS, van Greevenbroek MM, et al. Plasma proprotein convertase subtilisin kexin type 9 is not altered in subjects with impaired glucose metabolism and type 2 diabetes mellitus, but its relationship with non-HDL cholesterol and apolipoprotein B may be modified by type 2 diabetes mellitus: the CODAM study. Atherosclerosis. 2011;217(1):263-267.

41. Maxwell KN, Soccio RE, Duncan EM, Sehayek E, Breslow JL. Novel putative SREBP and LXR target genes identified by microarray analysis in liver of cholesterol-fed mice. J Lipid Res. 2003;44(11): 2109-2119.

42. Jeong HJ, Lee HS, Kim KS, Kim YK, Yoon D, Park SW. Sterol-dependent regulation of proprotein convertase subtilisin/kexin type 9 expression by sterol-regulatory element binding protein-2. J Lipid Res. 2008;49(2):399-409.

43. Horton JD, Shah NA, Warrington JA, et al. Combined analysis of oligonucleotide microarray data from transgenic and knockout mice identifies direct SREBP target genes. Proc Natl Acad Sci U S A. 2003;100(21): 12027-12032.

44. Awan Z, Seidah NG, MacFadyen JG, et al. Rosuvastatin, proprotein convertase subtilisin/kexin type 9 concentrations, and LDL cholesterol response: the JUPITER trial. Clin Chem. 2012;58(1): 183-189.

45. Chan DC, Lambert G, Barrett PH, Rye KA, Ooi EM, Watts GF. Plasma proprotein convertase subtilisin/kexin type 9: a marker of LDL apolipoprotein B-100 catabolism? Clin Chem. 2009;55(11): 2049-2052.

46. Cariou B, Ouguerram K, Zair Y, et al. PCSK9 dominant negative mutant results in increased LDL catabolic rate and familial hypobetalipoproteinemia. Arterioscler Thromb Vasc Biol. 2009;29(12):2191-2197.

47. Raal F, Panz V, Immelman A, Pilcher G. Elevated PCSK9 levels in untreated patients with heterozygous or homozygous familial hypercholesterolemia and the response to high-dose statin therapy. J Am Heart Assoc. 2013;2(2):e000028.

48. Tavori H, Fan D, Blakemore JL, et al. Serum proprotein convertase subtilisin/kexin type 9 and cell surface low-density lipoprotein receptor: evidence for a reciprocal regulation. Circulation. 2013;127(24): 2403-2413.

49. Welder G, Zineh I, Pacanowski MA, Troutt JS, Cao G, Konrad RJ. High-dose atorvastatin causes a rapid sustained increase in human serum PCSK9 and disrupts its correlation with LDL cholesterol. J Lipid Res. 2010;51(9):2714-2721.

50. Davignon J, Dubuc G. Statins and ezetimibe modulate plasma proprotein convertase subtilisin kexin-9 (PCSK9) levels. Trans Am Clin Climatol Assoc. 2009;120:163-173.

51. Charlton-Menys V, Durrington PN. Human cholesterol metabolism and therapeutic molecules. Exp Physiol. 2008;93(1):27-42.

52. Berthold HK, Seidah NG, Benjannet S, Gouni-Berthold I. Evidence from a randomized trial that simvastatin, but not ezetimibe, upregulates circulating PCSK9 levels. PLoS One. 2013;8(3):e60095.

53. Mayne J, Dewpura T, Raymond A, et al. Plasma PCSK9 levels are significantly modified by statins and fibrates in humans. Lipids Health Dis. 2008;7:22.

54. Nilsson LM, Abrahamsson A, Sahlin S, et al. Bile acids and lipoprotein metabolism: effects of cholestyramine and chenodeoxycholic acid on human hepatic mRNA expression. Biochem Biophys Res Commun. 2007;357(3):707-711.

55. Benjannet S, Rhainds D, Hamelin J, Nassoury N, Seidah NG. The proprotein convertase (PC) PCSK9 is inactivated by furin and/or PC5/6A: functional consequences of natural mutations and post-translational modifications. J Biol Chem. 2006;281(41):30561-30572.

56. Cohen J, Pertsemlidis A, Kotowski IK, Graham R, Garcia CK, Hobbs HH. Low LDL cholesterol in individuals of African descent resulting from frequent nonsense mutations in PCSK9. Nat Genet. 2005;37(2):161-165.

57. Aung LH, Yin RX, Miao L, et al. The proprotein convertase subtilisin/ kexin type 9 gene E670G polymorphism and serum lipid levels in the Guangxi Bai Ku Yao and Han populations. Lipids Health Dis. $2011 ; 10: 5$
58. Polisecki E, Peter I, Robertson M, et al. Genetic variation at the PCSK9 locus moderately lowers low-density lipoprotein cholesterol levels, but does not significantly lower vascular disease risk in an elderly population. Atherosclerosis. 2008;200(1):95-101.

59. Kotowski IK, Pertsemlidis A, Luke A, et al. A spectrum of PCSK9 alleles contributes to plasma levels of low-density lipoprotein cholesterol. Am J Hum Genet. 2006;78(3):410-422.

60. Norata GD, Garlaschelli K, Grigore L, et al. Effects of PCSK9 variants on common carotid artery intima media thickness and relation to ApoE alleles. Atherosclerosis. 2010;208(1):177-182.

61. Timms KM, Wagner S, Samuels ME, et al. A mutation in PCSK9 causing autosomal-dominant hypercholesterolemia in a Utah pedigree. Hum Genet. 2004;114(4):349-353.

62. Leren TP. Mutations in the PCSK9 gene in Norwegian subjects with autosomal dominant hypercholesterolemia. Clin Genet. 2004;65(5): 419-422.

63. Pisciotta L, Priore Oliva C, Cefalu AB, et al. Additive effect of mutations in LDLR and PCSK9 genes on the phenotype of familial hypercholesterolemia. Atherosclerosis. 2006;186(2):433-440.

64. Folsom AR, Peacock JM, Boerwinkle E, Atherosclerosis Risk in Communities Study I. Variation in PCSK9, low LDL cholesterol, and risk of peripheral arterial disease. Atherosclerosis. 2009;202(1):211-215.

65. Go AS, Mozaffarian D, Roger VL, et al. Heart disease and stroke statistics - 2014 update: a report from the American Heart Association. Circulation. 2014;129(3):e28-e292.

66. Law MR, Wald NJ, Thompson SG. By how much and how quickly does reduction in serum cholesterol concentration lower risk of ischaemic heart disease? BMJ. 1994;308(6925):367-372.

67. Goldstein J. Familial hypercholesterolemia. In: Scriver CR BA, Sly WS, Valle D, editors. The Metabolic and Molecular Bases of Inherited Disease. New York, NY, USA: McGraw-Hill; 2001.

68. Steinberg D. Lewis A. Conner Memorial Lecture. Oxidative modification of LDL and atherogenesis. Circulation. 1997;95(4):1062-1071.

69. von Eckardstein A, Nofer JR, Assmann G. High density lipoproteins and arteriosclerosis. Role of cholesterol efflux and reverse cholesterol transport. Arterioscler Thromb Vasc Biol. 2001;21(1):13-27.

70. Kannel WB, Dawber TR, Friedman GD, Glennon WE, McNamara PM. Risk factors in coronary heart disease. an evaluation of several serum lipids as predictors of coronary heart disease; the Framingham Study. Ann Intern Med. 1964;61:888-899.

71. Glomset JA, Janssen ET, Kennedy R, Dobbins J. Role of plasma lecithin:cholesterol acyltransferase in the metabolism of high density lipoproteins. J Lipid Res. 1966;7(5):638-648.

72. Hokanson JE, Austin MA. Plasma triglyceride level is a risk factor for cardiovascular disease independent of high-density lipoprotein cholesterol level: a meta-analysis of population-based prospective studies. J Cardiovasc Risk. 1996;3(2):213-219.

73. Varbo A, Benn M, Tybjaerg-Hansen A, Jorgensen AB, Frikke-Schmidt R, Nordestgaard BG. Remnant cholesterol as a causal risk factor for ischemic heart disease. J Am Coll Cardiol. 2013;61(4):427-436.

74. Emerging Risk Factors Collaboration; Danesh J, Erqou S, Walker M, et al. The Emerging Risk Factors Collaboration: analysis of individual data on lipid, inflammatory and other markers in over 1.1 million participants in 104 prospective studies of cardiovascular diseases. Eur J Epidemiol. 2007;22(12):839-869.

75. Emerging Risk Factors Collaboration; Di Angelantonio E, Sarwar N, Perry $\mathrm{P}$, et al. Major lipids, apolipoproteins, and risk of vascular disease. JAMA. 2009;302(18):1993-2000.

76. Emerging Risk Factors Collaboration; Di Angelantonio E, Gao P, Pennells L, et al. Lipid-related markers and cardiovascular disease prediction. JAMA. 2012;307(23):2499-2506.

77. Contois JH, McConnell JP, Sethi AA, et al. Apolipoprotein B and cardiovascular disease risk: position statement from the AACC Lipoproteins and Vascular Diseases Division Working Group on Best Practices. Clin Chem. 2009;55(3):407-419.

78. Konishi H, Miyauchi K, Kasai T, et al. Impact of lipoprotein(a) as residual risk on long-term outcomes in patients after percutaneous coronary intervention. Am J Cardiol. 2015;115(2):157-160. 
79. Zhao Z, Tuakli-Wosornu Y, Lagace TA, et al. Molecular characterization of loss-of-function mutations in PCSK9 and identification of a compound heterozygote. Am J Hum Genet. 2006;79(3): 514-523.

80. Hooper AJ, Marais AD, Tanyanyiwa DM, Burnett JR. The C679X mutation in PCSK9 is present and lowers blood cholesterol in a Southern African population. Atherosclerosis. 2007;193(2):445-448.

81. Cohen JC, Boerwinkle E, Mosley TH Jr, Hobbs HH. Sequence variations in PCSK9, low LDL, and protection against coronary heart disease. N Engl J Med. 2006;354(12):1264-1272.

82. Stein EA, Kasichayanula S, Turner T, et al. LDL cholesterol reduction with BMS-962476, an adnectin inhibitor of PCSK9: results of a single ascending dose study. J Am Coll Cardiol. 2014;63(12S).

83. Serometrix. Redeveloping pipelines from first principles. Available from: http://www.serometrix.com/pipeline.html. Accessed May 23, 2015 .

84. Fitzgerald K, Frank-Kamenetsky M, Shulga-Morskaya S, et al. Effect of an RNA interference drug on the synthesis of proprotein convertase subtilisin/kexin type 9 (PCSK9) and the concentration of serum LDL cholesterol in healthy volunteers: a randomised, single-blind, placebocontrolled, phase 1 trial. Lancet. 2014;383(9911):60-68.

85. Reuters. Pfizer developing PCSK 9 pill, vaccine to lower cholesterol. Available from: http://www.reuterSCom/article/2015/01/13/ us-healthcare-pfizer-cholesterol-idUSKBN0KM27A20150113. Accessed May 24, 2015.

86. Affiris. Atherosclerosis. Available from: http:/www.affiris.at/html/en/ impfstoffe/atherosklerose.html. Accessed May 24, 2015.

87. Careskey HE, Davis RA, Alborn WE, Troutt JS, Cao G, Konrad RJ. Atorvastatin increases human serum levels of proprotein convertase subtilisin/kexin type 9. J Lipid Res. 2008;49(2):394-398.

88. Berge KE, Ose L, Leren TP. Missense mutations in the PCSK9 gene are associated with hypocholesterolemia and possibly increased response to statin therapy. Arterioscler Thromb Vasc Biol. 2006;26(5):1094-1100.

89. Koren MJ, Lundqvist P, Bolognese M, et al. Anti-PCSK9 monotherapy for hypercholesterolemia: the MENDEL-2 randomized, controlled phase III clinical trial of evolocumab. J Am Coll Cardiol. 2014;63(23): 2531-2540.

90. Robinson JG, Nedergaard BS, Rogers WJ, et al. Effect of evolocumab or ezetimibe added to moderate- or high-intensity statin therapy on LDL-C lowering in patients with hypercholesterolemia: the LAPLACE-2 randomized clinical trial. JAMA. 2014;311(18): 1870-1882.

91. Blom DJ, Hala T, Bolognese M, et al. A 52-week placebo-controlled trial of evolocumab in hyperlipidemia. $N$ Engl J Med. 2014;370(19): 1809-1819.

92. Raal FJ, Stein EA, Dufour R, et al. PCSK9 inhibition with evolocumab (AMG 145) in heterozygous familial hypercholesterolemia (RUTHERFORD-2): a randomised, double-blind, placebo-controlled trial. Lancet. 2015;385(9965):331-340.

93. Raal FJ, Honarpour N, Blom DJ, et al. Inhibition of PCSK9 with evolocumab in homozygous familial hypercholesterolemia (TESLA Part B): a randomised, double-blind, placebo-controlled trial. Lancet. 2015;385(9965):341-350.

94. McKenney JM, Koren MJ, Kereiakes DJ, Hanotin C, Ferrand AC, Stein EA. Safety and efficacy of a monoclonal antibody to proprotein convertase subtilisin/kexin type 9 serine protease, SAR236553/ REGN727, in patients with primary hypercholesterolemia receiving ongoing stable atorvastatin therapy. J Am Coll Cardiol. 2012;59(25): 2344-2353.

95. Roth EM, McKenney JM. ODYSSEY MONO: effect of alirocumab $75 \mathrm{mg}$ subcutaneously every 2 weeks as monotherapy versus ezetimibe over 24 weeks. Future Cardiol. 2015;11(1):27-37.

96. Gaudet D, Kereiakes DJ, McKenney JM, et al. Effect of alirocumab, a monoclonal proprotein convertase subtilisin/kexin 9 antibody, on lipoprotein(a) concentrations (a pooled analysis of $150 \mathrm{mg}$ every two weeks dosing from phase 2 trials). Am J Cardiol. 2014;114(5): $711-715$.
97. Raal FJ, Giugliano RP, Sabatine MS, et al. Reduction in lipoprotein(a) with PCSK9 monoclonal antibody evolocumab (AMG 145): a pooled analysis of more than 1,300 patients in 4 phase II trials. $\mathrm{J} \mathrm{Am} \mathrm{Coll}$ Cardiol. 2014;63(13):1278-1288.

98. Dadu RT, Ballantyne CM. Lipid lowering with PCSK9 inhibitors. Nat Rev Cardiol. 2014;11(10):563-575.

99. Sabatine MS, Giugliano RP, Wiviott SD, et al. Efficacy and safety of evolocumab in reducing lipids and cardiovascular events. $N$ Engl J Med. 2015;372(16):1500-1509.

100. Robinson JG, Farnier M, Krempf M, et al. Efficacy and safety of alirocumab in reducing lipids and cardiovascular events. $N$ Engl J Med. 2015;372(16):1489-1499.

101. Postmus I, Trompet S, de Craen AJ, et al. PCSK9 SNP rs11591147 is associated with low cholesterol levels but not with cognitive performance or noncardiovascular clinical events in an elderly population. J Lipid Res. 2013;54(2):561-566.

102. Mancini GB, Tashakkor AY, Baker S, et al. Diagnosis, prevention, and management of statin adverse effects and intolerance: Canadian Working Group Consensus update. Can J Cardiol. 2013;29(12): 1553-1568.

103. Eckel RH. Approach to the patient who is intolerant of statin therapy. J Clin Endocrinol Metab. 2010;95(5):2015-2022.

104. Mampuya WM, Frid D, Rocco M, et al. Treatment strategies in patients with statin intolerance: the Cleveland Clinic experience. Am Heart J. 2013;166(3):597-603.

105. European Association for Cardiovascular Prevention and Rehabilitation; Reiner Z, Catapano AL, De Backer G, et al. ESC/EAS Guidelines for the management of dyslipidemias: the Task Force for the management of dyslipidemias of the European Society of Cardiology (ESC) and the European Atherosclerosis Society (EAS). Eur Heart J. 2011;32(14):1769-1818.

106. Keating AJ, Campbell KB, Guyton JR. Intermittent nondaily dosing strategies in patients with previous statin-induced myopathy. Ann Pharmacother. 2013;47(3):398-404.

107. Parker BA, Capizzi JA, Grimaldi AS, et al. Effect of statins on skeletal muscle function. Circulation. 013;127(1):96-103.

108. Sullivan D, Olsson AG, Scott R, et al. Effect of a monoclonal antibody to PCSK9 on low-density lipoprotein cholesterol levels in statin-intolerant patients: the GAUSS randomized trial. JAMA 2012;308(23):2497-2506.

109. Stroes E, Colquhoun D, Sullivan D, et al. Anti-PCSK9 antibody effectively lowers cholesterol in patients with statin intolerance: the GAUSS-2 randomized, placebo-controlled phase 3 clinical trial of evolocumab. J Am Coll Cardiol. 2014;63(23):2541-2548.

110. Stein EA, Gipe D, Bergeron J, et al. Effect of a monoclonal antibody to PCSK9, REGN727/SAR236553, to reduce low-density lipoprotein cholesterol in patients with heterozygous familial hypercholesterolemia on stable statin dose with or without ezetimibe therapy: a phase 2 randomised controlled trial. Lancet. 2012;380(9836):29-36.

111. Roth EM, McKenney JM, Hanotin C, Asset G, Stein EA. Atorvastatin with or without an antibody to PCSK 9 in primary hypercholesterolemia. N Engl J Med. 2012;367(20):1891-1900.

112. Moriarty PM, Jacobson TA, Bruckert E, et al. Efficacy and safety of alirocumab, a monoclonal antibody to PCSK9, in statin-intolerant patients: design and rationale of ODYSSEY ALTERNATIVE, a randomized phase 3 trial. J Clin Lipidol. 2014;8(6):554-561.

113. Moriarty PM Thompson PD, Cannon CP, et al. ODYSSEY ALTERNATIVE: efficacy and safety of the proprotein convertase subtilisin/kexin type 9 monoclonal antibody, alirocumab, versus ezetimibe, in patients with statin intolerance as defined by a placebo run-in and statin rechallenge arm. Available from: https://my.americanheart.org/idc/ groups/ahamah-public/@wcm/@sop/@scon/documents/downloadable/ ucm_469597.pdf. Accessed May 24, 2015.

114. Lennernas H. Clinical pharmacokinetics of atorvastatin. Clin Pharmacokinet. 2003;42(13):1141-1160.

115. Wilke RA, Lin DW, Roden DM, et al. Identifying genetic risk factors for serious adverse drug reactions: current progress and challenges. Nat Rev Drug Discov. 2007;6(11):904-916. 
116. Oh J, Ban MR, Miskie BA, Pollex RL, Hegele RA. Genetic determinants of statin intolerance. Lipids Health Dis. 2007;6:7.

117. Tabrizi MA, Tseng CM, Roskos LK. Elimination mechanisms of therapeutic monoclonal antibodies. Drug Discov Today. 2006;11(1-2): $81-88$.

118. Sattar N, Preiss D, Murray HM, et al. Statins and risk of incident diabetes: a collaborative meta-analysis of randomised statin trials. Lancet. 2010;375(9716):735-742.

119. Preiss D, Seshasai SR, Welsh P, et al. Risk of incident diabetes with intensive-dose compared with moderate-dose statin therapy: a metaanalysis. JAMA. 2011;305(24):2556-2564.
120. FiercePharma. Say what? CVS Health execs figure PCSK9 meds to cost up to \$150B. Available from: http://www.fiercepharma.com/story/ say-what-cvs-health-execs-figure-pcsk9-meds-cost-150b/2015-02-17. Accessed May 24, 2015.

121. Stone NJ, Robinson JG, Lichtenstein AH, et al. 2013 ACC/AHA guideline on the treatment of blood cholesterol to reduce atherosclerotic cardiovascular risk in adults: a report of the American College of Cardiology/American Heart Association Task Force on Practice Guidelines. Circulation. 2014;129(25 Suppl 2):S1-S45.

\section{Publish your work in this journal}

Research Reports in Clinical Cardiology is an international, peerreviewed, open access journal publishing original research, reports, editorials, reviews and commentaries on all areas of cardiology in the clinic and laboratory. The manuscript management system is completely online and includes a very quick and fair peer-review system.
Visit http://www.dovepress.com/testimonials.php to read real quotes from published authors. 